\title{
BODY SIZE, DIET AND ENDOPARASITES OF THE MICROHYLID FROG Chiasmocleis capixaba IN AN ATLANTIC FOREST AREA OF SOUTHERN BAHIA STATE, BRAZIL
}

\author{
VAN SLUYS, M. ${ }^{1}$, SCHITTINI, G. M. ${ }^{1}$, MARRA, R. V. ${ }^{1}$, AZEVEDO, A. R. M. ${ }^{1}$, \\ VICENTE, J. J. ${ }^{2}$ and VRCIBRADIC, D. ${ }^{1}$ \\ ${ }^{1}$ Departamento de Ecologia, IBRAG, Universidade do Estado do Rio de Janeiro, Rua São Francisco Xavier, 524, Maracanã, \\ CEP 20550-013, Rio de Janeiro, RJ, Brazil \\ ${ }^{2}$ Laboratório de Helmintos Parasitos de Vertebrados, Departamento de Helmintologia, Fundação Instituto Oswaldo Cruz, \\ C. P. 926, CEP 21041-210, Rio de Janeiro, RJ, Brazil \\ Correspondence to: Monique Van Sluys, Departamento de Ecologia, IBRAG, Universidade do Estado do Rio de Janeiro, \\ Rua São Francisco Xavier, 524, Maracanã, CEP 20550-013, Rio de Janeiro, RJ, Brazil, e-mail: vansluys@uerj.br \\ Received May 27, 2004 - Accepted August 20, 2004 - Distributed February 28, 2006
}

(With 1 figure)

\begin{abstract}
We analyzed the diet composition, endoparasites and sexual size dimorphism of the microhylid frog Chiasmocleis capixaba (Microhylidae) from a "mussununga" habitat in the municipality of Nova Viçosa, southern Bahia state, Brazil. All the 119 specimens analyzed were collected in a single night of heavy rainfall. Females (mean snout-vent length $=15.7+3.0 \mathrm{~mm}$ ) were significantly larger than males (mean snout-vent length $=13.2+2.1 \mathrm{~mm}$ ), and specimens of both sexes were smaller than those of a conspecific population previously reported in Aracruz, state of Espírito Santo state. The diet of $C$. capixaba was dominated by mites, ants and collembolans. Seventy-nine frogs $(66.4 \%$ of the total) were infected by helminths, all belonging to a single species, Cosmocerca ornata, an intestinal nematode parasite.
\end{abstract}

Keywords: Chiasmocleis capixaba, diet, sexual size dimorphism, parasites, Atlantic rainforest.

\section{RESUMO}

\section{Tamanho corporal, dieta e endoparasitas do anuro microhilídeo Chiasmocleis capixaba em uma área de Floresta Atlântica no sul do Estado da Bahia, Brasil}

Analisamos a composição da dieta, endoparasitas e dimorfismo sexual em tamanho no anuro Chiasmocleis capixaba (Microhylidae) em um habitat de "mussununga" no município de Nova Viçosa, no sul do Estado da Bahia, Brasil. Todos os 119 espécimes analisados foram coletados em uma única noite com chuva intensa. As fêmeas (comprimento rostro-cloacal médio $=15,7+3,0 \mathrm{~mm}$ ) foram significativamente maiores que os machos (comprimento rostro-anal médio $=13,2 \pm 2,1 \mathrm{~mm}$ ), e indivíduos de ambos sexos foram menores do que os de uma população coespecífica de Aracruz, no Estado do Espírito Santo. A dieta de C. capixaba estava dominada por ácaros, formigas e colêmbolos. Setenta e nove indivíduos $(66.4 \%$ do total) estavam infectados por helmintos, todos pertencentes a uma única espécie, Cosmocerca ornata, um nematódeo intestinal.

Palavras-chave: Chiasmocleis capixaba, dieta, dimorfismo em tamanho, parasitas, Floresta Atlântica.

\section{INTRODUCTION}

The anuran family Microhylidae is represented in South America by the subfamilies Microhylinae and Otophryninae (Kasahara \& Haddad, 1997; Frost, 2002), the former comprising most of the Neotropical species. Microhylines are generally terrestrial and most taxa are fossorial or semifossorial (Zug et al., 2001). The genus Chiasmocleis, the most specious and widespread among Neotropical microhylids, is currently 
composed of 18 species distributed from Panama to southern Brazil (Caramaschi \& Cruz, 1997, 2001; Cruz et al., 1997; Caramaschi \& Pimenta, 2003). Of these species, eight occur in the Atlantic rainforest biome in eastern Brazil (Caramaschi \& Pimenta, 2003). Frogs of this genus are known to be explosive breeders (sensu Wells, 1977), forming mating aggregations that sometimes involve hundreds of individuals occupying temporary water bodies during a very short period of the year (Crump, 1974; Cruz et al., 1997; Haddad \& Hödl, 1997; Kasahara \& Haddad, 1997). Because of this short breeding period, frogs of the genus Chiasmocleis are not commonly found in nature (Kasahara \& Haddad, 1997) and, not surprisingly, little is known about many aspects of their life histories. Most available information concerns their reproductive biology, including call characteristics and activity, tadpole description and reproductive behavior (Crump, 1974; Hero, 1990; Hödl, 1990; Schlüter \& Salas, 1991; Haddad \& Hödl, 1997; Kasahara \& Haddad, 1997; Segalla \& Langone, 1999; Hartmann et al., 2002). There is also some information on defense strategies and commensalism for one Amazonian species (Cocroft \& Hambler, 1989; Schlüter \& Salas, 1991). Partial information on feeding habits is available for four species (all Amazonian), indicating that ants are generally the predominant items in their diet (Duellman, 1978; Schlüter \& Salas, 1991; Caramaschi \& Cruz, 2001).

Chiasmocleis capixaba Cruz et al., 1997 is a small eastern Brazilian species of Chiasmocleis that lives on the leaf litter of the forest ground, in lowland Atlantic Forest from southern Bahia state to Espírito Santo state (Cruz et al., 1997; Van Sluys, 1998). These frogs reproduce explosively, with males and females congregating in temporary ponds in the forest (Cruz et al., 1997). Nothing further is known of this species' natural history. In the present study, we analyzed the diet composition, endoparasites and size dimorphism in a population of C. capixaba from southern Bahia state, Brazil.

\section{METHODS}

The frogs were collected during an anuran faunal survey in April 1997, in a 'mussununga' habitat in the municipality of Nova Viçosa (17 53' 31' S/39 22' 19" W), southern Bahia state. The vegetation was old growth secondary forest with many palms and vines. The area is the property of Aracruz Celulose S. A. Two systems of pitfall traps with drift fences were built. Each system was $80 \mathrm{~m}$ long and contained six pitfalls (100-litre bowls). These systems were left open for $48 \mathrm{~h}$ and were checked twice a day (in the morning and afternoon).

After a night of heavy rain (April 7), more than 300 individuals of C. capixaba were found dead in the pitfalls (which were full of water) and on the ground around them (see Van Sluys, 1998). The animals were collected, fixed in $10 \%$ formalin and preserved in $70 \%$ alcohol. Specimens were deposited at the National Museum, Rio de Janeiro (MNRJ 18924-19025, 19052-19274). Because there is no information of minimum size at maturity for Chiasmocleis species, we could not confidently separate adults from subadults and thus analyses and comparisons of body size were based on all the individuals measured.

In the laboratory, the frogs' snout-vent length (SVL) and jaw width (JW) were measured with digital calipers (precision of $0.1 \mathrm{~mm}$ ), and the animals were weighed to the nearest $0.01 \mathrm{~g}$ on an electronic balance. We compared body and jaw sizes between males and females using Student's t-test (Zar, 1999). The digestive tract of each frog was removed for analysis of the diet and associated endoparasite (helminths) fauna.

Stomach contents were analyzed under a stereomicroscope. Each prey found was identified to Order and its maximum length and width measured to the nearest $0.1 \mathrm{~mm}$. The volume of each type of prey was estimated using a modified version of the formula for a prolate spheroid: Volume $=4 / 3 \pi($ length $/ 2) \times(\text { width } / 2)^{2}($ Vitt et al. , 1996). An Importance Index $(I)$ was calculated, as in Howard et al. (1999): $I_{x}=\left\{\left(\mathrm{n}_{\mathrm{x}} / \mathrm{N}\right)+\left(\mathrm{v}_{\mathrm{x}} / \mathrm{V}\right)\right.$ $\left.+\left(f_{x} / F\right)\right\} / 3$, where $n_{x}, v_{x}$, and $f_{x}$ are the number, volume, and frequency of prey item $\mathrm{x}$, respectively, and $\mathrm{N}, \mathrm{V}$, and $\mathrm{F}$ of all prey items. $I_{x}$ represents the relative importance of a particular type of prey in relation to the entire diet.

We examined the entire digestive tract of each frog, looking for helminths. All helminths found were transferred to acetic acid and then to phenol (for diaphanization) and mounted on temporary slides for identification under a microscope. The total number of individual helminths of each species was quantified and their location (according to 
each portion of the digestive tract - stomach, small intestine and large intestine) was recorded. The prevalence (sensu Bush et al., 1997) was calculated as the percentage of infected hosts. To calculate the mean intensity of infection (sensu Bush et al., 1997), we used the arithmetic mean (+ one SD) of all helminths found in infected frogs. We tested for differences between males and females in the prevalence using the Z-test for proportions (Zar, 1999). To test for differences between males and females in the intensity of infection, we used the Student t-test (Zar, 1999). We analyzed the effect of ontogenetic variation on the intensity of infection using simple linear regression analysis (Zar, 1999). Voucher specimens of the helminths were deposited at the helminthological collection of the Instituto Oswaldo Cruz (CHIOC) under the numbers 35305-9.

\section{RESULTS AND DISCUSSION}

We analyzed 119 individuals (74 males and 45 females). Females ranged from 10.2 to $20.2 \mathrm{~mm}$ in SVL whereas males ranged from 9.8 to $18.0 \mathrm{~mm}$. Mean body size was significantly larger for females (mean SVL $=15.7+3.0 \mathrm{~mm}$ ) than for males (mean SVL $=13.2+2.1 \mathrm{~mm} ; \mathrm{t}$-test: $\mathrm{t}=-5.308 ;$ $\mathrm{df}=117 ; \mathrm{P}<0.001)$. Head width also differed between sexes, with females having wider jaws (mean $\mathrm{JW}=4.1+0.6 \mathrm{~mm}$; range: $2.9-5.4 \mathrm{~mm}$ ) than males (mean $\mathrm{JW}=3.8+0.4 \mathrm{~mm}$; range: 2.8 - $4.7 \mathrm{~mm}$; t- test: $-2.774 ; \mathrm{df}=117 ; \mathrm{P}=0.006$ ). The relationship between body size and jaw width differed in slope between males and females $\left(r=0.72 ; F_{3,115}=41.837 ; P<0.001 ;\right.$ Fig. 1). Males and females from the southern Bahia C. capixaba population studied here were smaller both in body size and jaw width than those of the population from Aracruz, Espírito Santo State, the type locality of the species (males: mean SVL $=15.6 \mathrm{~mm}$; range: $14.7-16.5 \mathrm{~mm}$; mean $\mathrm{JW}=4.9 \mathrm{~mm}$; range: 4.6 - 5.3; $\mathrm{N}=12$; females: mean $\mathrm{SVL}=20.2 \mathrm{~mm}$; range: $17.9-21.7 \mathrm{~mm}$; mean $\mathrm{JW}=5.7 \mathrm{~mm}$; range: 5.4-6.2 mm; $\mathrm{N}=16$; Cruz et al., 1997). As our sample size was much larger than that of Cruz et al. (1997), we could not tell if these size differences resulted from the difference in sample size or from actual interpopulational variation in frog body sizes, as in some other anuran species from the Brazilian Atlantic forest biome (Dias \& Cruz, 1993; Rico et al., 2004).

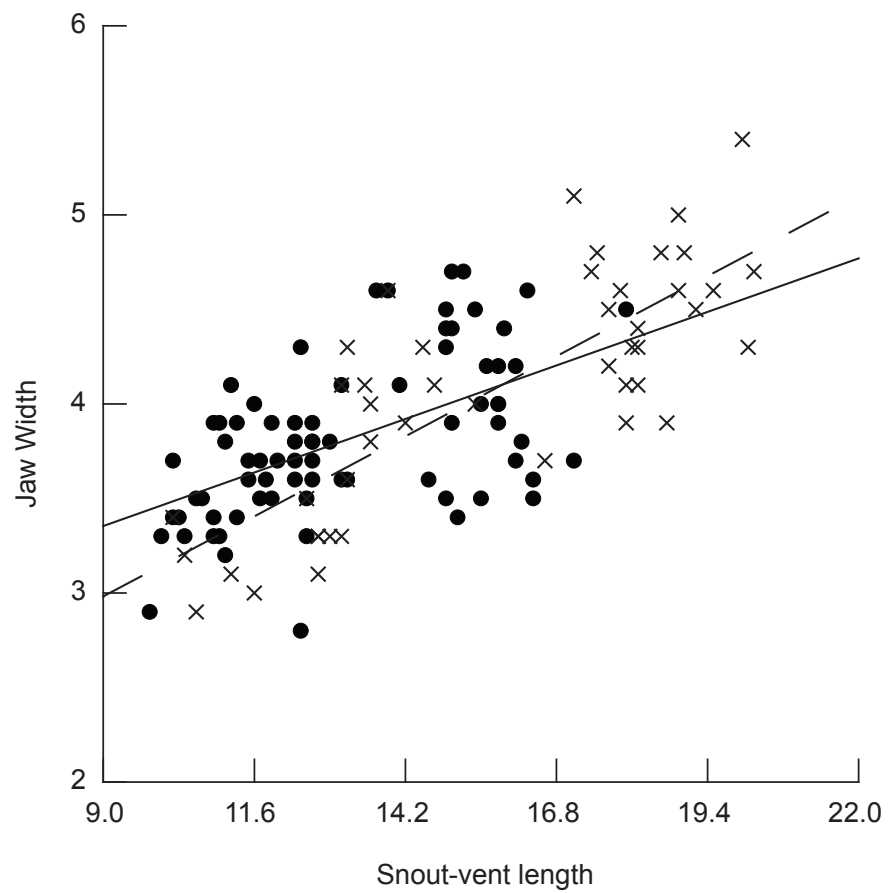

Fig. 1 - Relationship between body size (Snout-vent length, in $\mathrm{mm}$ ) and jaw width (JW, in $\mathrm{mm}$ ) for males (circles, full line) and females (crosses, dashed line) of Chiasmocleis capixaba from southern Bahia state, northeastern Brazil. 
Twenty-three individuals $(9$ males and 14 females) had empty stomachs and were thus excluded from the diet analysis. Schlüter \& Salas (1991) examined 220 stomachs of C. ventrimaculata from a Peruvian rainforest and found most of them to be empty, whereas in our sample of 119 C. capixaba, only $19 \%$ of the frogs had empty stomachs. Chiasmocleis capixaba ate predominantly mites, ants and collembolans (Table 1). Mites were the most frequent (93.8\%) and numerous ( $46.7 \%$ ) prey ingested by males, whereas ants were the most frequent $(90.3 \%)$ and numerous $(66.4 \%)$ prey consumed by females (Table 1).
However, according to the index of importance $\left(I_{x}\right)$ values, ants were the most important prey for both males and females (Table 1).

Jaw width did not affect $(\mathrm{P}>0.05)$ any of the prey size measurements (mean volume of prey ingested, length of the largest prey, mean length of the five largest prey) analyzed (Table 2). In general, a significant relationship between mouth dimensions and prey sizes is expected for frogs because they do not chew their prey, thus being restricted to eating items that fit in their mouths (Lima \& Moreira, 1993), although Simon \& Toft (1991) argue that this relationship depends on the

TABLE 1

Diet composition of Chiasmocleis capixaba $(\mathbf{N}=96)$ at a 'mussununga' habitat in Nova Viçosa, Bahia, Brazil. $F=$ number of frogs with that prey type; $N=$ number of prey found in stomachs; $\mathrm{V}=$ total volume $\left(\mathrm{mm}^{3}\right)$ of prey types; and $I_{x}=$ importance index.

\begin{tabular}{|c|c|c|c|c|c|c|c|c|}
\hline \multirow[b]{2}{*}{ Prey } & \multicolumn{4}{|c|}{ Males $(N=65)$} & \multicolumn{4}{|c|}{ Females $(\mathbf{N}=\mathbf{3 1})$} \\
\hline & $\mathbf{F}(\%)$ & $\mathbf{N}(\%)$ & $\mathrm{V}(\%)$ & $I_{x}$ & $\mathrm{~F}(\%)$ & $\mathbf{N}(\%)$ & $\mathrm{V}(\%)$ & $I_{x}$ \\
\hline $\begin{array}{l}\text { Hymenoptera } \\
\text { Formicidae }\end{array}$ & $\begin{array}{l}51 \\
(78.46)\end{array}$ & $\begin{array}{l}245 \\
(39.07)\end{array}$ & $\begin{array}{l}176.95 \\
(68.84)\end{array}$ & 0.621 & $\begin{array}{l}28 \\
(90.32)\end{array}$ & $\begin{array}{l}235 \\
(66.38)\end{array}$ & $\begin{array}{l}155.00 \\
(76.84)\end{array}$ & 0.778 \\
\hline $\begin{array}{l}\text { Winged } \\
\text { Hymenoptera }\end{array}$ & $\begin{array}{l}2 \\
(3.08) \\
\end{array}$ & $\begin{array}{l}2 \\
(0.32) \\
\end{array}$ & $\begin{array}{c}1.83 \\
(0.71) \\
\end{array}$ & 0.014 & - & - & - & - \\
\hline Coleoptera & $\begin{array}{l}6 \\
(9.23)\end{array}$ & $\begin{array}{l}6 \\
(0.96)\end{array}$ & $\begin{array}{c}1.00 \\
(0.39)\end{array}$ & 0.035 & - & - & - & - \\
\hline Isoptera & $\begin{array}{l}6 \\
(9.23) \\
\end{array}$ & $\begin{array}{l}19 \\
(3.03)\end{array}$ & $\begin{array}{l}17.01 \\
(6.62) \\
\end{array}$ & 0.063 & $\begin{array}{l}2 \\
(6.45) \\
\end{array}$ & $\begin{array}{l}6 \\
(1.69) \\
\end{array}$ & $\begin{array}{c}5.09 \\
(2.52) \\
\end{array}$ & 0.035 \\
\hline Diptera & $\begin{array}{l}1 \\
(1.54)\end{array}$ & $\begin{array}{l}1 \\
(0.16)\end{array}$ & $\begin{array}{c}0.08 \\
(0.03)\end{array}$ & 0.006 & - & - & - & - \\
\hline Larvae & $\begin{array}{c}6 \\
(9.23) \\
\end{array}$ & $\begin{array}{l}13 \\
(2.07) \\
\end{array}$ & $\begin{array}{l}17.11 \\
(6.66) \\
\end{array}$ & 0.060 & - & - & - & - \\
\hline Collembola & $\begin{array}{l}21 \\
(32.31) \\
\end{array}$ & $\begin{array}{l}32 \\
(5.10)\end{array}$ & $\begin{array}{c}0.64 \\
(0.25) \\
\end{array}$ & 0.125 & $\begin{array}{c}8 \\
(25.81) \\
\end{array}$ & $\begin{array}{l}17 \\
(4.80)\end{array}$ & $\begin{array}{c}0.82 \\
(0.41) \\
\end{array}$ & 0.103 \\
\hline Pseudoscorpionida & - & - & - & - & $\begin{array}{l}1 \\
(3.23) \\
\end{array}$ & $\begin{array}{l}1 \\
(0.28) \\
\end{array}$ & $\begin{array}{c}1.14 \\
(0.57) \\
\end{array}$ & 0.014 \\
\hline Acarina & $\begin{array}{l}61 \\
(93.85) \\
\end{array}$ & $\begin{array}{l}293 \\
(46.73)\end{array}$ & $\begin{array}{c}32.88 \\
(12.79) \\
\end{array}$ & 0.511 & $\begin{array}{l}22 \\
(70.97) \\
\end{array}$ & $\begin{array}{l}93 \\
(26.27) \\
\end{array}$ & $\begin{array}{r}6.59 \\
(3.27) \\
\end{array}$ & 0.335 \\
\hline Araneae & $\begin{array}{l}6 \\
(9.23) \\
\end{array}$ & $\begin{array}{l}7 \\
(1.12) \\
\end{array}$ & $\begin{array}{c}2.27 \\
(0.88) \\
\end{array}$ & 0.037 & - & - & - & - \\
\hline Diplopoda & $\begin{array}{l}4 \\
(6.15) \\
\end{array}$ & $\begin{array}{l}4 \\
(0.64) \\
\end{array}$ & $\begin{array}{c}1.46 \\
(0.57) \\
\end{array}$ & 0.024 & $\begin{array}{c}1 \\
(3.23) \\
\end{array}$ & $\begin{array}{c}1 \\
(0.28) \\
\end{array}$ & $\begin{array}{c}0.57 \\
(0.28) \\
\end{array}$ & 0.013 \\
\hline Chilopoda & $\begin{array}{l}4 \\
(6.15) \\
\end{array}$ & $\begin{array}{l}4 \\
(0.64) \\
\end{array}$ & $\begin{array}{c}3.46 \\
(1.35) \\
\end{array}$ & 0.027 & - & - & - & - \\
\hline Gastropoda & - & - & - & - & $\begin{array}{c}1 \\
(3.23)\end{array}$ & $\begin{array}{l}1 \\
(0.28)\end{array}$ & $\begin{array}{c}0.31 \\
(0.15)\end{array}$ & 0.012 \\
\hline Arthropod remains & - & - & - & - & - & - & $\begin{array}{c}32.18 \\
(15.96) \\
\end{array}$ & - \\
\hline Total & - & 627 & 257.04 & - & 354 & 201.71 & - & - \\
\hline
\end{tabular}


taxon in question. Probably, the lack of a mouth size-prey size relationship in $C$. capixaba results from the small range of body sizes and the small size of the frogs, which also limits the size range of potential prey.

Comparing the food habits of C. capixaba with those of other Chiasmocleis species (Duellman, 1978; Schlüter \& Salas, 1991; Caramaschi \& Cruz, 2001), we may conclude that ants, in general, are very important prey for these frogs. Moreover, Schlüter \& Salas (1991) categorized C. ventrimaculata (Andersson, 1945) as 'ant-specialist' in the sense of Toft (1980). However, without information on relative prey availability in the habitat, we could not conclude whether the preponderance of ants resulted from their being more abundant than other prey types or if frogs preferentially consumed those insects independently of their local availability.

Mites were the second most important item in the diet of C. capixaba. Mites are among the commonest soil and litter arthropods in several areas, but are infrequently reported in frog diets (Simon \& Toft, 1991). Considering the terrestrial habits and small body size of $C$. capixaba, the consumption of mites by this frog is not unexpected, although previously studied species of Chiasmocleis do not appear to be important predators of mites in forest litter communities (Simon \& Toft, 1991). Duellman (1978) did not report mites in the diet of Chiasmocleis anatipes Walker \& Duellman, 1974, C. bassleri Dunn, 1949 and C. ventrimaculata. For the latter species, Schlüter \& Salas (1991) reported having observed two individuals feeding on mites at night, but did not mention finding any in the stomachs they analyzed. However, a large amount of the diet of some other Microhylids, such as the very small western Amazonian species Syncope antenori Walker, 1973, consists of mites (see Table 2 of Simon \& Toft, 1991). Indeed, Simon
\& Toft (1991) found the degree of acariphagy in frogs to be inversely related to body size, as one might expect. All C. capixaba examined, except one female, were smaller than $20 \mathrm{~mm}$. Sixty-five percent of the frogs analyzed were smaller than $15 \mathrm{~mm}$ (Class 1 of Simon \& Toft, 1991) and in this size class, mites were consumed by $93.6 \%$ of the frogs. These numbers are higher than those reported by Simon \& Toft (1991) for the microhylids they analyzed and indicate that mites are an important component of the diet of $C$. capixaba in southern Bahia. Considering that C. capixaba is one of the smallest species in the genus (for comparisons see Caramaschi \& Cruz, 1997, 2001; Cruz et al., 1997; Caramaschi \& Pimenta, 2003), it is not surprising that it preys on mites more frequently than other congeners. However, these studies do not provide information on the frequency of occurrence of the different types of prey, thus preventing us from further analyzing the effect of body size differences among species on their diet composition.

The only parasites found in the digestive tract of C. capixaba were nematodes of the species Cosmocerca ornata, Diesing, 1861 (Cosmocercoidea; Cosmocercidae), which always occurred in the intestines and was present in 79 individuals (i.e., total prevalence of $66.4 \%$ ). Prevalence was high for both males $(63.5 \%$; 47/74) and females (71.1\%; 32/45), and did not differ between sexes (Z-test: $\mathrm{Z}=-0.851$; $\mathrm{P}=0.197$ ). Mean infection intensity (sensu Bush et al., 1997) was higher for females (mean intensity $=3.5+2.6$, range $=1-11$ ) than for males (mean intensity $=2.3+1.3$; range $=1-6$; t-test; $\mathrm{t}=-2.834 ; \mathrm{df}=77 ; \mathrm{p}=0.06$ ). The body size of frogs significantly affected the number of nematodes found in both sexes, with larger frogs harboring more parasites (females: $\mathrm{R}^{2}=0.37$; $\mathrm{F}_{1,29}=17.15 ; \mathrm{p}<0.001 ;$ males: $\mathrm{R}^{2}=0.19$; $\left.\mathrm{F}_{1,47}=11.26 ; \mathrm{p}=0.02\right)$.

TABLE 2

Statistics of the relationships between jaw width and three measures of prey size for $C$. capixaba $(\mathrm{N}=119)$ from Nova Viçosa, Bahia, Brazil.

\begin{tabular}{|l|c|c|c|}
\hline Prey size measures & $\mathbf{R}^{2}$ & F & P \\
\hline Mean length of the five largest prey & 0.03 & 0.988 & 0.402 \\
\hline Length of the largest prey & 0.01 & 0.293 & 0.831 \\
\hline Mean volume of prey & 0.06 & 1.917 & 0.132 \\
\hline
\end{tabular}


Cosmocerca ornata has already been found in other anuran species from both the New and Old Worlds (Baker, 1987; Aisien et al., 2001). Chiasmocleis capixaba represents a new host record for this nematode. In the Americas, $C$. ornata has been previously reported only from Paraguay (Baker \& Vaucher, 1984); thus, the present study represents its second record from the New World and the first from Brazil.

Helminth communities of amphibians are generally regarded as depauperate (Aho, 1990). Based on an extensive literature survey, Aho (1990) found a mean helminth richness per host species of 3.54 and an overall mean richness per host individual of 0.98 in anuran amphibians (his dataset was, however, dominated by North American taxa). In the present study, only one helminth species was found infecting $C$. capixaba, although the mean helminth richness per host individual (0.66) was close to that of Aho (1990). Overall mean helminth abundance (sensu Bush et al., 1997) per host reported by Aho (1990) was 11.55. The helminth fauna of $C$. capixaba in our study area is therefore extremely depauperate and characterized by low infection rates, even compared to those of other small South American anuran species (Azevedo-Ramos et al., 1998; Kehr et al., 2000). The positive relationship between body size and parasite intensity observed for C. capixaba is not unexpected, and reflects the influence of both temporal (time of exposure to potential parasites during life) and spatial (available space inside the host) factors on infection rates (e.g., Aho, 1990; Van Sluys et al., 1994). This relationship may also explain why females had, on average, more parasites than males, since they are the larger sex in C. capixaba. However, the influence of host sex on endoparasite loads of amphibians is variable among different host and parasite species, and appears to have more complex causes than simply the size of hosts (e.g., Lees, 1962; Hollis, 1972; Kehr et al., 2000).

We conclude that the microhylid C. capixaba is a "carnivorous" frog feeding mainly on ants and mites. There is sexual size dimorphism, with females being larger than males, as appears to be the norm in this genus (see Caramaschi \& Cruz, 1997, 2001; Cruz et al., 1997; Caramaschi \& Pimenta, 2003). The fauna of gut helminths is poor, comprising only one species. However, the lack of previous data on these ecological aspects for this and other Chiasmocleis species precludes further conclusions.

Acknowledgments - This study is part of the results of the "Ecology, Conservation and Management of Southeastern Brazilian Ecosystems Program" and of the Southeastern Brazilian Vertebrate Ecology Project (Vertebrate Ecology Laboratory), both of the Dept. of Ecology, Universidade do Estado do Rio de Janeiro. The field work was carried out while the first author was working as a consultant for Aracruz Celulose S. A. We thank Aracruz Celulose S. A. for the opportunity to work at Nova Viçosa and for all the facilities provided. We would also like to thank Beatrice Allain, who reviewed the text of this work. RVM holds a graduate fellowship from the Conselho Nacional do Desenvolvimento Científico e Tecnológico (\# 141636/2003-3) and MVS holds a research grant from CNPq (\# 302405/02-0). This study was partially supported by a grant from CNPq (\# 477981/03-8) and was carried out under permit \# 022/97 from IBAMA.

\section{REFERENCES}

AHO, J. M., 1990, Helminth communities of amphibians and reptiles: comparative approaches to understanding patterns and processes, pp. 157-195. In: G. W. ESCH, A. O. BUSH \& J. M. AHO (eds.), Parasite Communities: Patterns and Processes. Chapman and Hall, New York.

AISIEN, O. S., UGBO, A. D., ILAVBAR A. N. \& OGUNBOR, O., 2001, Endoparasites of amphibians from South-Western Nigeria. Acta Parasitol., 46(4): 299-305.

AZEVEDO-RAMOS, C., SANTOS, M. M. Q. \& OLIVEIRA, V. R. L., 1998, Helminths of three Amazonian treefrogs: interspecific differences in prevalence and infection intensity of parasites. Ci. e Cul., 50: 361-363.

BAKER, M. R., 1987, Synopsis of the nematoda parasitic in amphibians and reptiles. Mem. Univ. Newfoundland, Occ. Pap. Biol., 11: 1-325.

BAKER, M. R. \& VAUCHER., C., 1984, Parasitic helminths from Paraguay VI: Cosmocerca Diesing, 1861 (Nematoda: Cosmocercoidea) from frogs. Rev. Suisse Zool., 91(4): 925-934.

BUSH, A. O., LAFFERTY, K. D., LOTZ, J. M. \& SHOSTAK, A. W., 1997, Parasitology meets ecology in its own terms: Margolis et al. revisited. J. Parasitol., 83(4): 575-583.

CARAMASCHI, U. \& CRUZ, C. A. G., 1997, Redescription of Chiasmocleis albopunctata (Boettger) and description of a new species of Chiasmocleis (Anura: Microhylidae). Herpetologica, 53(2): 259-268.

CARAMASCHI, U. \& CRUZ, C. A. G., 2001, A new species of Chiasmocleis Méhelÿ, 1904 from brazilian Amazonia (Amphibia, Anura, Microhylidae). Bol. Mus. Nacional, Rio de Janeiro, 469: 1-8.

CARAMASCHI, U. \& PIMENTA, B. V. S., 2003, Duas novas espécies de Chiasmocleis Méhely, 1904 da Mata Atlântica do sul da Bahia, Brasil (Amphibia; Anura; Microhylidae). Arquiv. Mus. Nacional, Rio de Janeiro, 61(3): 195-202.

COCROFT, R. B. \& HAMBLER, K., 1989, Observations on a commensal relationship of the microhylid frog Chiasmocleis ventrimaculata and the burrowing theraphosid spider 
Xenesthis immanis in Southeastern Peru. Biotropica, 21(1): 2-8.

CRUMP, M. L., 1974, Reproductive strategies in a tropical anuran community. Misc. Publ. Univ. Kansas 61: 1-67.

CRUZ, C. A. G., CARAMASCHI, U. \& IZECKSOHN, E., 1997, The genus Chiasmocleis Méhely, 1904 (Anura, Microhylidae) in the Atlantic Rainforest of Brazil with description of three new species. Alytes, 15(2): 49-71.

DIAS, A. G. \& CRUZ, C. A. G., 1993, Análise das divergências morfológicas de Hyla bipunctata Spix em duas populações dos Estados de Rio de Janeiro e Espírito Santo, Brasil (Amphibia, Anura, Hylidae). Rev. Brasil. Zool., 10(3): 439-441

DUELLMAN, W. E., 1978, The biology of an equatorial herpetofauna in Amazonian Ecuador. Univ. Kansas Mus. Nat. Hist., Misc. Publ., 65: 1-352.

FROST, D. R., 2002, Amphibian Species of the World: an online reference. V2.21 (15 July 2002). Electronic database availableathttp://research.amnh.org/herpetology/amphibia/ index.html.

HADDAD, C. F. B. \& HÖDL, W., 1997, A new reproductive mode in anurans: bubble nest in Chiasmocleis leucosticta (Anura, Microhylidae). Copeia, 1997(3): 585-588.

HARTMANN, M. T., HARTMANN, P. A. \& HADDAD, C. F. B., 2002, Advertisement calls of Chiasmocleis carvalhoi, Chiasmocleis mehely and Myersiella microps (Microhylidae). J. Herpetol., 36(3): 509-511.

HERO, J-M., 1990, An illustrated key to tadpoles occurring in the Central Amazon rainforest, Manaus, Amazonas, Brasil. Amazoniana, 11(2): 201-262.

HÖDL, W., 1990, Reproductive diversity in Amazonian lowland frogs. Fortschr. Zool., 38: 41-60.

HOLLIS, P. D., 1972, Host sex influence on the seasonal incidence of Haematoloechus medioplexus (trematoda: Plagiorchiidae) in Rana pipiens. J. parasitol., 58(1): 128.

HOWARD, A. K., FORRESTER, J. D., RUDER, J. M., PARMERLEE JR., J. S. \& POWELL R., 1999, Natural history of a terrestrial Hispaniolan anole: Anolis barbouri. J. Herpetol., 33(4): 702-706.

KASAHARA, S. \& HADDAD, C. F. B., 1997, Karyotypes of two brazilian microhylid frogs of the genus Chiasmocleis, including a new case of polyploidy. J. Herpetol., 31(1):139-142.
KEHR, A., MANLY, B. F. J. \& HAMANN, M. I., 2000, Coexistence of helminth species in Lysapsus limellus (Anura: Pseudidae) from an Argentinean subtropical area: influence of biotic and abiotic factors. Oecologia, 125(4): 549-558

LEES, E., 1962, The incidence of helminth parasites in a particular frog population. Parasitology, 53(1): 95-102.

LIMA, A. P. \& MOREIRA, G., 1993, Effects of prey size and foraging mode on the ontogenetic change in feeding niche of Colostethus stepheni (Anura: Dendrobatidae). Oecologia, 95(1): 93-102.

RICO, M., ROCHA, C. F. D., BORGES JR., V. N. \& VAN SLUYS., M., 2004, Breeding ecology of Scinax trapicheiroi (Anura, Hylidae) at a creek in the Atlantic Rainforest of Ilha Grande, southeastern Brazil. Amphibia-Reptilia, 25(3): 277-286.

SEGALLA, M. V. \& LANGONE, J. A., 1999, Sobre la oviposición de Chiasmocleis leucosticta (Boulenger, 1888) (Anura, Microhylidae). Cuad. Herp., 13(1-2): 97-98.

SCHLÜTER, A. \& SALAS, A. W., 1991, Reproduction, tadpoles and ecological aspects of three syntopic microhylid species from Peru (Amphibia: Microhylidae). Stuttgarter Beitr. Naturk., 458(A): 1-17.

SIMON, M. P. \& TOFT, C., 1991, Diet specialization in small vertebrates: mite-eating in frogs. Oikos, 61(2): 263-278.

TOFT, C., 1980, Feeding ecology of thirteen syntopic species of anurans in a seasonal tropical environment. Oecologia, 45(1): 131-141.

VAN SLUYS, M., 1998, Geographic Distribution. Chiasmocleis capixaba. Herpetol. Rev., 29(2): 106-107.

VAN SLUYS, M., ROCHA, C. F. D. \& RIBAS, S. C., 1994, Nematodes infecting the lizard Tropidurus itambere in southeastern Brazil. Amphibia-Reptilia, 15(4): 405-408.

VITT, L. J., ZANI, P. A. \& CALDWELL, J. P., 1996, Behavioural ecology of Tropidurus hispidus on isolated rock outcrops in Amazonia. J. Trop. Ecol., 12(1): 81-101.

WELLS, K. D., 1977, The social behavior of anuran amphibians. Anim. Behav., 25(3): 666-693.

ZAR, J. H., 1999, Biostatistical Analysis. Prentice Hall, Inc., Inglewood Cliffs, NY., 663p.

ZUG, G. R., VITT, L. J. \& CALDWELL, J. L., 2001, Herpetology. An Introductory Biology of Amphibians and Reptiles. $2^{\text {nd }}$ Ed. Academic Press, San Diego. 630p. 